https://doi.org/10.5194/bg-2020-424

Preprint. Discussion started: 24 November 2020

(C) Author(s) 2020. CC BY 4.0 License.

(c) (i)

\title{
1 Do marine benthos breathe what they eat?
}

2

3 Xiaoguang Ouyang, Cheuk Yan Lee, Shing Yip Lee

4 Simon F.S. Li Marine Science Laboratory, School of Life Sciences, The Chinese University of

5 Hong Kong, Shatin, Hong Kong SAR, China

6

7 Correspondence to:

$8 \quad$ Xiaoguang Ouyang (email: x.ouyang@cuhk.edu.hk)

$9 \quad$ Shing Yip Lee (email: joesylee@cuhk.edu.hk)

10

11 


\section{Abstract}

Intertidal benthos link tertiary predators and primary producers in marine food webs as well as directly contribute to sediment $\mathrm{CO}_{2}$ emission. However, current methods for studying food sources of marine benthos are time-consuming and does not allow direct estimates on feeding regime-related $\mathrm{CO}_{2}$ production. We examined the foods of mangrove crabs and gastropods as well as their corresponding $\mathrm{CO}_{2}$ production by using cavity-ring down spectroscopy to measure the $\delta^{13} \mathrm{C}$ of consumer-respired $\mathrm{CO}_{2}$, considering the effects of feeding regime, benthos taxa, and dominant feeding habit. Benthos taxa and feeding habit have significant impact on $\delta^{13} \mathrm{C}$ of

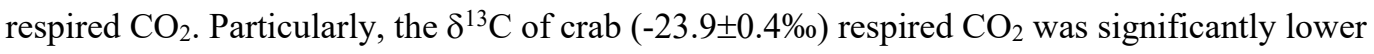

21 than that from gastropod $\left(-17.5 \pm 1.3 \%\right.$ ) respiration. The $\delta^{13} \mathrm{C}$ of deposit-feeder respired $\mathrm{CO}_{2}$ was

22 significantly higher than that from detritivores. There are significant differences in the amount of

$23 \mathrm{CO}_{2}$ emitted and $\delta^{13} \mathrm{C}$ of crab respired $\mathrm{CO}_{2}$ under different feeding regimes. The differences

24 reflect diet-switching and fuel-switching in the crabs, i.e. 'you breathe what you eat'. Significant

25 differences in $\mathrm{CO}_{2}$ production of crabs also exist between those feeding on microphytobenthos

$26\left(0.13 \pm 0.02 \mathrm{mmol} \mathrm{g}^{-1} \mathrm{day}^{-1}\right)$ and on field collection $\left(0.31 \pm 0.03 \mathrm{mmol} \mathrm{g}^{-1} \mathrm{day}^{-1}\right) . \mathrm{CO}_{2}$ production

27 of crabs is strongly related to carapace width and length. The $\delta^{13} \mathrm{C}$ of respired $\mathrm{CO}_{2}$ from

28 mangrove crabs reflects their diet while crab-respired $\mathrm{CO}_{2}$ flux is related to crab size. These

29 relationships enable partitioning the feeding habit and food sources of key benthos, and help

30 incorporate their contribution into the overall sediment-atmosphere $\mathrm{CO}_{2}$ fluxes in mangroves. 


\section{Introduction}

33 Intertidal benthos are well known to play different roles in processing nutrients in the intertidal

34 food webs depending on their taxonomic affiliation and feeding habit. In mangroves, sesarmid

35 crabs are reported to use mangrove leaf litter as the most important carbon source, with diatoms

36 or live/dead animal prey as the dominant nitrogen source, while ocypodid crabs and gastropods

37 are mainly deposit feeders, preferring the microphytobenthos (Kristensen et al., 2017; Lee,

38 2008). The different feeding habits (e.g. detritivorous or deposit-feeding) of the mangrove

39 benthos may result in differences in their metabolic processes. Past mangrove studies revealing

40 the food sources of the mangrove benthos have advanced from earlier gut analysis to stable

41 isotope analyses (Lee et al., 2014). Stable isotope analysis unravels benthic food sources by

42 extracting benthos muscle tissues and analyzing tissue and food stable isotope values of carbon,

43 nitrogen and occasionally sulfur (Bui \& Lee, 2014; Chong et al., 2001). However, dietary

44 analysis is a time-consuming process that often requires close monitoring of individual predators

45 or collection and analyses of prey remains in the gut or faeces of the predator (Caro, 1994;

46 Wachter et al., 2012).

47 In contrast to traditional stable isotope analyses of predator tissues, $\delta^{13} \mathrm{C}$ of predator-respired

$48 \mathrm{CO}_{2}$ have increasingly been applied to study the food sources and feeding habit of predators. The

49 latter approach has advantages over isotope analyses of predator tissues because it can provide

50 information about both the most recently consumed diet and the integrated diet over longer

51 periods (Engel et al., 2009). While some adults of aerial and aquatic migratory species occupy

52 intertidal habitats during specific seasons of the year, others are permanent inhabitants

53 (Vernberg, 1993). The variable feeding habits of marine migratory species make it useful to

54 study both their immediate diet and integrated diets. In contrast, some tissues (e.g. muscles) have 
55 slower turnover rates and their isotopes can only reflect the integrated diet over longer periods

56 (Carleton et al., 2004). Further, breath $\delta^{13} \mathrm{C}$ can be repeatedly measured non-destructively for the

57 same predator and thus can track the changes in its food sources. Carleton et al. (2004) explored

58 the use of $\delta^{13} \mathrm{C}$ of hummingbirds exhaled $\mathrm{CO}_{2}$ to demonstrate their shift from a $\mathrm{C} 3$ to $\mathrm{C} 4$ diet.

59 Voigt et al. (2008) found free-ranging vampire bats prefer cattle blood by analyzing $\delta^{13} \mathrm{C}$ of their

60 respired $\mathrm{CO}_{2}$. Its application was also tested in other animals such as grasshoppers (Engel et al.,

61 2009). $\delta^{13} \mathrm{C}$ of predator-respired $\mathrm{CO}_{2}$ is sufficient for quickly unravelling the prey consumed

62 without the involvement of diet and predator tissue $\delta^{13} \mathrm{C}$ values. However, this approach still

63 remains uncommon in marine studies for examining the food of marine benthos.

64 Moreover, the measurement of benthos-respired $\mathrm{CO}_{2}$ and their isotope signatures does not only reveals their food sources but also helps assess their contribution to sediment respiration

66 after adjusting for the effects of feeding habit and regime (e.g. active vs. dormant status, and

67 feeding on microphytobenthos vs. yellow leaves). $\mathrm{CO}_{2}$ emission rates from the sediment surface

68 of mangroves are more than doubled if the contribution of marine benthos and their burrows is

69 included (Kristensen et al., 2008; Ouyang et al., 2017; Penha-Lopes et al., 2010). Some crabs

70 may remain dormant most of the time, with a short active period (e.g. 90 days, Katz (1980))

71 during the year. Should the starved condition during dormant periods be unaccounted for, it may

72 lead to erroneous estimations on the animals' contribution to $\mathrm{CO}_{2}$ emission from the sediment

73 surface. Further, it is well established that $\mathrm{C} 3$ and $\mathrm{C} 4$ plants have distinct isotope signatures (Fry,

74 2006), which may result in differences in $\delta^{13} \mathrm{C}$ of benthos-respired $\mathrm{CO}_{2}$. Nonetheless, few studies

75 explore whether the increase in $\mathrm{CO}_{2}$ emission rates due to marine benthos is related to feeding

76 regime or their feeding habit. 
Cavity ring-down spectroscopy (CRDS) is one of the most recent advances in measuring the concentration as well as isotopic values of many biogenic gases, including $\mathrm{CO}_{2}, \mathrm{CH}_{4}$, and other gases that have unique near-infrared absorption spectra. CRDS works by quantifying the effect of this absorption (Welch Jr et al., 2016). It has been used in marine studies to partition sources of ecosystem and sediment respiration of mangrove seedlings (Ouyang et al., 2018), and the variation of $\delta^{13} \mathrm{C}$ of greenhouse gases emitted from estuaries and other ecosystems (Jacotot et al., 2018; Munksgaard et al., 2014; Rosentreter et al., 2018; Sea et al. 2018; Ouyang et al., 2020).

We conducted the first study using CRDS to relate the feeding regimes of different intertidal benthos with $\delta^{13} \mathrm{C}$ of their respired $\mathrm{CO}_{2}$. We also measured the different isotope enrichment between marine benthos-respired $\mathrm{CO}_{2}$ and their diets for different benthos taxa and feeding habits. The relationship between benthos size and feeding regime to their $\mathrm{CO}_{2}$ production was also assessed. Intertidal benthos are hypothesised to "breathe what they eat" in terms of both breath $\delta^{13} \mathrm{C}$ and $\mathrm{CO}_{2}$ production. We explored the influence of benthic taxa, feeding regime and feeding habit on the $\delta^{13} \mathrm{C}$ of benthos-respired $\mathrm{CO}_{2}$ and/or benthos $\mathrm{CO}_{2}$ production (i.e. $\mathrm{CO}_{2}$ respired per unit mass per day), and the relationship between benthos $\mathrm{CO}_{2}$ production and their body sizes through laboratory experiments. We put forward the novel paradigm 'You Breathe What You Eat', which adds to the well-known paradigm of 'You Are What You Eat' in food web studies. This study will inform future efforts to estimate the contribution of different food sources to the diet of mangrove benthos over both short and long periods.

\subsection{Sample collection}


99 We collected small (2-4 cm carapace width) but numerically dominant brachyuran crabs

100 (including sesarmids, varunids and ocypodids) and gastropods from the mangrove forests in Mai

101 Po Nature Reserve $\left(22^{\circ} 30^{\prime} \mathrm{N}, 11^{\circ} 02^{\prime} \mathrm{E}\right)$ and Ting Kok $\left(22^{\circ} 28^{\prime} \mathrm{N}, 114^{\circ} 13^{\prime} \mathrm{E}\right)$, Hong Kong.

102 Senescent leaves of the mangrove Kandelia obovata were hand-picked from the trees. The leaves

103 can be identified by their yellow colour and easily detachable from the branches. Surface

104 sediments (down to $1 \mathrm{~cm}$ ) were collected by a syringe with the needle end removed. The samples

105 were kept on ice before transportation to the laboratory.

106

107

\subsection{Sample pre-treatment and separation}

108 Each animal was kept in a small container with seawater covering the bottom to avoid desiccation. The animal food items were treated and/or purified before the consumption experiments. Upon return to the laboratory, the leaves were immersed in seawater for around 24

111 hours to allow leaching of deterrent chemicals such as tannins, which may deter crabs from

112 feeding. Microphytobenthos (MPB), mainly in the form of diatoms, were separated from the

113 surface sediments by the 'sieve and spin' method (Bui \& Lee 2014). Specifically, the sediments

114 were suspended in seawater and sieved through a $45 \mu \mathrm{m}$ mesh. The filtrate was further passed

115 through a $5 \mu \mathrm{m}$ filter, and the residue was resuspended in Ludox colloidal silica (Sigma, density

$1161.34 \mathrm{~g} \mathrm{ml}^{-1}$ ). Then the mixture was vortexed and centrifuged at $4000 \mathrm{rpm}$ for 10 minutes. The

117 microphytobenthos concentrated in a distinct layer at the top of the colloidal silica were then

118 separated via a pipette, before confirming to be predominantly microphytobenthos using a

119 microscope. The MPB was washed in Milli Q water to remove the remnant colloidal silica and

120 washed again when the microphytobenthos had settled down. This process was repeated several 
121 times until the water was clear. The MPB were then collected on pre-combusted GF/F filters

122 (Whatman).

123

124

\subsection{Experimental design}

We conducted a series of experiments to examine factors influencing $\mathrm{C}$ isotopic signatures and/or $\mathrm{CO}_{2}$ production of the mangrove benthos: (1) the effect of benthic taxa (i.e. crabs vs. gastropods); (2) the effect of feeding regime (on collection vs. fasted, feeding on yellow mangrove leaves vs. diatoms). Mangrove benthos "on collection" and "fasted" correspond to the active and dormant status of benthos, respectively; (3) the effect of feeding habit (i.e. deposit feeders vs. detritivores); and (4) the relationship between $\mathrm{CO}_{2}$ production and animal body size. Thirty animals were used each in experiments (1) and (3), while 10 sesarmid crabs were used in experiment (2), and 25 animals (sesarmid crabs and gastropods) in experiment 4.

In experiment (1), the animals were put in plastic 0.81 containers covered by aluminium foil to minimise disturbance. There is a small hole on the lid of each container to keep the pressure balance between the inside and outside of the containers. A soft plastic hose was connected to the lid of each container with the other end closed by a stop-cock. Twenty minutes after closing each container, a syringe was connected to the other outlet of the stop-cock, and $30 \mathrm{ml}$ of gas was collected from the container. The needle end of the syringe was also closed by a stop-cock until analysis. Gases were collected over a period of 50 minutes (five times, every 10 minutes). In experiment (2), gas samples were collected similarly collected upon arrival at the laboratory as well as under starving conditions each day for three days to simulate the dormant status. Afterwards, they were fed with mangrove leaves and then, after fasting for 3 days, fed with MPB. Gas samples were collected separately when the crabs were fed on different foods. In 
144 experiment (3), the benthos were fed treated yellow leaves or MPB, depending on their main feeding habits. Deposit feeders, including gastropods (e.g. Terebralia sulcata), ocypodid crabs (e.g. Uca arcuata) and varunid crabs (e.g. Metaplax longipes), were fed MPB. Detritivores,

147 including sesarmid crabs, e.g. Parasesarma bidens and $P$. pictum, were fed yellow mangrove 148 leaves.

\subsection{Sample analysis and measurement}

In experiment (4), the carapace width (CW) and length (CL) of crabs and shell length of gastropods were measure by Vernier callipers. After measuring $\mathrm{CO}_{2}$ production as described above, the crabs were sacrificed and dried at $60^{\circ} \mathrm{C}$ until constant weight. Subsamples of dried leaf and MPB samples (around $5 \mathrm{mg}$ ) were weighed into tin capsules for stable isotope analysis. Another group of crabs were dissected and muscle tissues extracted, dried and prepared in the same way for stable isotope analysis. Their elemental contents (carbon and nitrogen), $\delta^{13} \mathrm{C}$ and $\delta^{15} \mathrm{~N}$ values were analysed by a EuroVector Elemental Analyser - Nu Perspective Isotope Ratio Mass Spectrometer (IRMS) at The University Hong Kong, with iACET standards used for quality control check.

$160 \quad \mathrm{CO}_{2}$ and $\mathrm{CH}_{4}$ concentrations and $\delta^{13} \mathrm{C}$ values of the gas samples were measured by a Picarro

161 G 2201-i CRDS analyser (Picarro Inc., USA). The syringes were connected to the inlet of CRDS 162 analyser to allow gas to be sucked into the analyser by a vacuum pump. The analyser measured $163 \delta^{13} \mathrm{CO}_{2}, \mathrm{CO}_{2}$ and $\mathrm{CH}_{4}$ concentrations at an interval of five seconds with guaranteed precision of $164<0.012 \%, 200 \mathrm{ppb}+0.005 \%$ and $50 \mathrm{ppb}+0.05 \%$, respectively. Standard gases of mixed $\mathrm{CO}_{2}$ 165 (1008 ppm) and $\mathrm{CH}_{4}(10.2 \mathrm{ppm})$ (ARK NIC, West Indices) were used to check the accuracy of 166 the analyser. 

space (Dawson et al., 2002). It is described by the isotope mixing model and mass balance model as below:

$$
\left[\mathrm{CO}_{2}\right]_{\mathrm{system}}=\left[\mathrm{CO}_{2}\right]_{\text {sample }}+\left[\mathrm{CO}_{2}\right]_{\text {source }}
$$

where $\delta^{13} \mathrm{C}_{\text {system }}, \delta^{13} \mathrm{C}_{\text {source }}, \delta^{13} \mathrm{C}_{\text {atm }}$ are the $\delta^{13} \mathrm{C}$ values for the system, the source and sample space, respectively. $\left[\mathrm{CO}_{2}\right]_{\text {system, }}\left[\mathrm{CO}_{2}\right]_{\text {source }}$ and $\left[\mathrm{CO}_{2}\right]_{\text {sample }}$ are the concentrations for the system, the source and sample space, respectively. The equations (1) and (2) can be combined and rearranged as below

$$
\delta^{13} \mathrm{C}_{\text {system }}=\delta^{13} \mathrm{C}_{\text {source }}+\left[\mathrm{CO}_{2}\right]_{\text {sample }}\left(\delta^{13} \mathrm{C}_{\text {sample }}-\delta^{13} \mathrm{C}_{\text {source }}\right) \frac{1}{\left[\mathrm{CO}_{2}\right]_{\text {system }}}
$$

The same principle can be applied to measure $\delta^{13} \mathrm{C}$ of benthos- and other animal-respired $\mathrm{CO}_{2}$, as discussed elsewhere (Carleton et al., 2004). As indicated in equation (3), the y-intercept of a linear regression of $\delta^{13} \mathrm{C}_{\text {system }}$ against $\frac{1}{\left[\mathrm{CO}_{2}\right]_{\text {system }}}$ provides an estimate $\delta^{13} \mathrm{C}$ of benthos-respired $\mathrm{CO}_{2} .\left[\mathrm{CO}_{2}\right]_{\text {source }}$ was estimated as the slope of the regression relationship between $\left[\mathrm{CO}_{2}\right]_{\text {system }}$ $(t=0,10,20,30$ and 40 minutes) and $t$. A conceptual model was used to describe the process of measuring benthos $\mathrm{CO}_{2}$ production and $\delta^{13} \mathrm{C}$ of respired $\mathrm{CO}_{2}$ by CRDS (Fig. 1)

186 The containers used to collect greenhouse gases respired by the animals are similar to a static 187 chamber, for which the respired greenhouse gas flux $\left(\mathrm{mmol} \mathrm{day}^{-1}\right)$ was standardized across the diet treatments and estimated as below 


$$
\mathrm{F}=V\left(\frac{d[\mathrm{CO} 2] \text { source }}{d t}\right) \frac{1}{\mathrm{~V}_{0}} \frac{P}{P_{0}} \frac{T_{0}}{T}
$$

190 Where $\mathrm{V}$ is the chamber volume subtracting the volume of the crab. $\frac{d[\mathrm{CO} 2] \text { source }}{d t}$ is usually taken 191 to be the slope of the linear regression of $\left[\mathrm{CO}_{2}\right]_{\text {source }}$ on $\mathrm{t}$ (Rolston, 1986). Here $\mathrm{t}$ is the series of 192 gas collection time from the start to end, i.e. every 10 minutes for five times. $\mathrm{V}_{0}$ is the gas molar volume under standard conditions. $\mathrm{P}_{0}$ and $\mathrm{T}_{0}$ is the standard pressure and temperature. $\mathrm{P}$ and $\mathrm{T}$ is the pressure and temperature in the container.

\subsection{Statistical analysis}

We conducted a two-way analysis of variance (ANOVA) to examine the impact of benthos taxa and feeding habit on $\delta^{13} \mathrm{C}$ of benthos-respired $\mathrm{CO}_{2}$. When significant treatment effects were found, Tukey's HSD test was used to detect difference among groups. We also conducted a oneway ANOVA to examine the impact of feeding regime on $\delta^{13} \mathrm{C}$ of benthos-respired $\mathrm{CO}_{2}$ and benthic $\mathrm{CO}_{2}$ production. Before ANOVA, the assumptions of normality and homoscedasticity were tested $(\alpha=0.05)$. Normality was tested using the Shapiro-Wilk normality test. Homoscedasticity was tested using the Levene test. Linear regression was used to examine the relationships between crab $\mathrm{CO}_{2}$ production and carapace width/length/ weight, as well as between gastropod $\mathrm{CO}_{2}$ production and shell length/weight. The assumption of normality was tested as described above. Given only significant relationships were found for sesarmid crabs, student's $t$ test was performed to test the difference in the ratios of carapace length and width between ocypodid crabs and sesarmid crabs, to show if the relationship between $\mathrm{CO}_{2}$ production of sesarmid crabs and crab size applies to ocypodid crabs. Student's t test was also used to

210 compare (1) the difference in $\mathrm{C} / \mathrm{N}$ ratios; (2) $\delta^{13} \mathrm{C}$ and $\delta^{15} \mathrm{~N}$ values between mangrove yellow

211 leaves and the microphytobenthos; and (3) $\delta^{13} \mathrm{C}$ of $\mathrm{CO}_{2}$ respired by crabs on collection and that 
212 of muscle tissues. Data are presented as mean \pm standard error (SE). All the data analyses were

213 conducted using R programming language (R Core Team, 2014). The R package 'car' was used

214 to conduct ANOVA (Fox \& Weisberg, 2011).

2163 Results

\section{$217 \quad 3.1$ The sources of variations of $\delta^{\mathbf{1 3}} \mathrm{C}$ of intertidal benthos respired $\mathrm{CO}_{2}$}

Our results show that $\delta^{13} \mathrm{C}$ of intertidal benthos respired $\mathrm{CO}_{2}$ varied significantly with benthos taxa, dominant feeding habit and/or feeding regime. Benthos taxa (1) and dominant feeding habit

(2) had a significant influence on $\delta^{13} \mathrm{C}$ of benthos-respired $\mathrm{CO}_{2}$ (ANOVA, $\mathrm{F}_{1}=48.4, \mathrm{P}<<0.001$;

$\left.\mathrm{F}_{2}=12.9, \mathrm{P}<<0.001\right)$. Further post-hoc analyses showed that the $\delta^{13} \mathrm{C}$ of $\mathrm{crab}(-23.9 \pm 0.4 \%$ )

HSD test, $\mathrm{P}<<0.001$, Fig. 2a). The $\delta^{13} \mathrm{C}$ of deposit-feeders (e.g. Terebralia sulcata and Uca

arcuata) respired $\mathrm{CO}_{2}(-19.8 \pm 0.8 \%$ ) was significantly higher than those of detritivores (e.g.

Parasesarma bidens) respired $\mathrm{CO}_{2}(-24.7 \pm 0.3 \%$, Tukey’s HSD test, $\mathrm{P}=0.004$, Fig. 2 b). regimes (ANOVA, $\mathrm{F}=5.4, \mathrm{P}<0.001$, Fig. 3). In particular, $\delta^{13} \mathrm{C}$ of crab-respired $\mathrm{CO}_{2}$ was

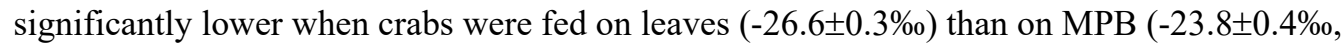
$\mathrm{P}<0.001)$, and on collection $(-24.8 \pm 0.6 \%, \mathrm{P}<0.05)$. This is consistent with the diet $\delta^{13} \mathrm{C}$ values. $\delta^{13} \mathrm{C}$ values of mangrove yellow leaves were significantly lower $(-27.8 \pm 0.2 \%)$ than those of the MPB $(-27.1 \pm 0.05 \%)(t=-3.8, p<0.01$, Fig. $2 c)$. In contrast, the ratio of $\mathrm{C} / \mathrm{N}$ for mangrove yellow leaves $(95 \pm 1.8)$ was significantly higher than that for the MPB $(16.3 \pm 0.3)(t=44.307$, $\mathrm{p}<<0.001$, Fig. $2 \mathrm{~d}$ ). $\delta^{13} \mathrm{C}$ of benthos-respired $\mathrm{CO}_{2}$ was also significantly higher when crabs fed 
on MPB than when they were fasted for 2 days $(-25.7 \pm 0.4 \%, \mathrm{P}<0.05)$ and 3 days $(-25.8 \pm 0.4 \%$,

$\mathrm{P}<0.05)$. Further, $\delta^{13} \mathrm{C}$ of $\mathrm{CO}_{2}$ respired by detritivorous crabs on collection $(-24.0 \pm 0.6 \%$ ) was not significantly different from that of crab muscles $(-22.6 \pm 0.6 \%, \mathrm{P}>0.05)$. Also no significant differences were found between other comparisons.

238

\subsection{Variation of $\mathrm{CO}_{2}$ production with benthos size and/or feeding regimes}

$\mathrm{CO}_{2}$ production was related to consumer size and/or feeding regimes. There was a significant difference in $\mathrm{CO}_{2}$ production of crabs among different feeding regimes (ANOVA, $\mathrm{F}=2.9$, $\mathrm{P}<0.05$, Fig. 4). In particular, $\mathrm{CO}_{2}$ production of crabs was significantly lower when they fed on MPB $\left(0.13 \pm 0.02 \mathrm{mmol} \mathrm{g}^{-1}\right.$ day $\left.^{-1}\right)$ than on collection $\left(0.31 \pm 0.03 \mathrm{mmol} \mathrm{g}^{-1}\right.$ day $\left.^{-1}, \mathrm{P}<0.05\right)$ or fasted for one day $\left(0.3 \pm 0.05 \mathrm{mmol} \mathrm{g}^{-1}\right.$ day $\left.^{-1}, \mathrm{P}<0.05\right)$. No significant differences were found for other comparisons. There were significant relationships between $\mathrm{CO}_{2}$ production of crabs and carapace width $\left(\mathrm{R}^{2}=0.73, \mathrm{P}<0.001\right.$, Fig. 5a), and between $\mathrm{CO}_{2}$ production of crabs and carapace length $\left(\mathrm{R}^{2}=0.61, \mathrm{P}<0.01\right.$, Fig. $\left.5 \mathrm{~b}\right)$. Significant differences were found in the ratios of carapace length and width between ocypodid crabs $(0.59 \pm 0.002)$ and sesarmid crabs $(0.79 \pm 0.025)$ ( $\mathrm{t}$ test, $\mathrm{t}=-7.9$, $\mathrm{P}<0.01$ ), which application of the above relationships for intraspecific comparison may depend on the size measurement used. The $\mathrm{CO}_{2}$ production of the crabs was $0.45 \pm 0.05 \mathrm{mmol} \mathrm{g}^{-1}$ day $^{-1}$ at

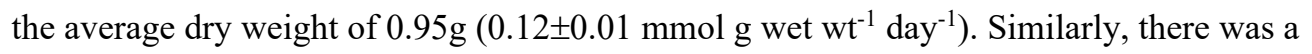
significant relationship between $\mathrm{CO}_{2}$ production of gastropods and shell length $\left(\mathrm{R}^{2}=0.58\right.$, $\mathrm{P}<0.05$, Fig. 5c). The $\mathrm{CO}_{2}$ production of the gastropods was $0.014 \pm 0.003 \mathrm{mmol} \mathrm{g}^{-1} \mathrm{day}^{-1}$ at the average dry weight of $2.09 \mathrm{~g}(0.045 \mathrm{~g}$ without shell). No significant relationships were found between $\mathrm{CO}_{2}$ production and crab or gastropod weight $(\mathrm{P}>0.05)$. 


\section{Discussion}

\subsection{Differences in $\delta^{13} \mathrm{C}$ of intertidal benthos due to different food categories}

Our data suggest that $\delta^{13} \mathrm{C}$ of benthos-respired $\mathrm{CO}_{2}$ can be used to infer the categories of benthos foods being used. The $\delta^{13} \mathrm{C}$ of benthos-respired $\mathrm{CO}_{2}$ in the gastropod group was higher than that of the crab group, and that of the deposit-feeding group was higher than the detritivorous group. These different patterns may reflect different food categories of the mangrove benthos. In our laboratory experiment, the gastropods investigated mainly forage on the MPB, while the crabs may use both the MPB and mangrove leaf litter depending on their feeding habit. Yellow leaves of mangrove species in Ting Kok (where leaves and sediments were collected) have $\delta^{13} \mathrm{C}$ at $27.8 \pm 0.16 \%$ and $\mathrm{C} / \mathrm{N}$ at $95 \pm 1.8$, while the corresponding values for MPB were $-27.1 \pm 0.05 \%$ and 16.3 \pm 0.3 . A C $/ \mathrm{N}$ ratio of $<20$ is generally required for sustainable animal nutrition (RussellHunter, 1970). Thus, crabs may need to use the MPB or other N-rich sources to meet their nutritional requirement to supplement the low-N leaf diets. The isotopic fractionation $\left(\Delta^{13} \mathrm{C}\right)$ is $3.2 \%$ and $3.9 \%$ between $\delta^{13} \mathrm{C}$ of crab $\left(-23.9 \pm 0.4 \%\right.$ ) respired $\mathrm{CO}_{2}$ and $\delta^{13} \mathrm{C}$ of MPB and mangrove yellow leaves respectively, while it is $9.6 \%$ between $\delta^{13} \mathrm{C}$ of gastropod (-17.5 $\pm 1.3 \%$ ) respired $\mathrm{CO}_{2}$ and $\delta^{13} \mathrm{C}$ of the MPB (Table 1). Similarly, $\Delta^{13} \mathrm{C}$ is $7.3 \%$ between $\delta^{13} \mathrm{C}$ of depositfeeder (including ocypodid and varunid crabs and gastropods) respired $\mathrm{CO}_{2}(-19.8 \pm 0.8 \%)$ and $\delta^{13} \mathrm{C}$ of the MPB and 3.1\% between $\delta^{13} \mathrm{C}$ of detritivore (including sesarmid crabs) respired $\mathrm{CO}_{2}$ $(-24.7 \pm 0.3 \%)$ and $\delta^{13} \mathrm{C}$ of yellow mangrove leaves. The lack of significant difference between $\delta^{13} \mathrm{C}$ of $\mathrm{CO}_{2}$ respired by detritivorous crabs on collection and that of crab muscles is consistent with findings on terrestrial herbivores (Engel et al. 2009). 
The significant differences in $\delta^{13} \mathrm{C}$ of crab-respired $\mathrm{CO}_{2}$ among different feeding regimes may be attributed to fuel-switching and also to food categories consumed. Proteins, lipids and carbohydrates are the three major classes of metabolic fuels (McCue \& Welch, 2016). The longstanding paradigm lies in that fasting animals pass through three sequential physiological phases whereby they predominantly oxidize endogenous fuels in the sequence of carbohydrates, followed by lipids, and then proteins (Caloin, 2004; Castellini \& Rea, 1992). $\delta^{13} \mathrm{C}$ of crabrespired $\mathrm{CO}_{2}$ was not significantly different among the MPB diet, on collection or starved for one day, but was significantly higher compared to that of crabs starved for two or three days. In our experiment, crabs may metabolise carbohydrates and/or mixed with lipids when they were just collected or fasted for one day, similar to the small animals in another study (Carleton et al., 2004). After fasting for two or three days, crabs started to consume lipids, which have $\delta^{13} \mathrm{C}$ values $0.5-8 \%$ lower than those of carbohydrates (DeNiro \& Epstein, 1977; McCue \& Welch, 2016; Stott et al., 1997). This can explain the decline (but non-significant) in $\delta^{13} \mathrm{C}$ of crabrespired $\mathrm{CO}_{2}$ during the fasting periods. After fasted for three days, $\delta^{13} \mathrm{C}$ of crab-respired $\mathrm{CO}_{2}(-$ $26.6 \pm 0.3 \%$ ) was about $1.2 \%$ higher than when they fed on yellow Kandelia obovata leaves. Similarly, $\delta^{13} \mathrm{C}$ of crab-respired $\mathrm{CO}_{2}(-23.8 \pm 0.4 \%$ ) was about $3.3 \%$ higher than the diet when they fed on MPB after starvation. These results are supported by the higher $\delta^{13} \mathrm{C}_{\text {breath }}$ values than $\delta^{13} C_{\text {diet }}(0.8-3.1 \%$ o for different animals including steers, pigs and rabbit (Passey et al., 2005).

\subsection{Differences in benthos $\mathrm{CO}_{2}$ production due to body size and feeding regime}

300 The significant relationships between benthos $\mathrm{CO}_{2}$ production and body size suggest that animal

301 size distribution should be considered when estimating the contribution of the benthos to $\mathrm{CO}_{2}$

302 emission rates from the sediment surface. $\mathrm{Crab} \mathrm{CO}_{2}$ production $\left(0.12 \mathrm{mmol} \mathrm{g}^{-1}\right.$ wet wt day $\left.{ }^{-1}\right)$ for 
the sesarmid crabs in our study falls within the reported range of $0.05-0.15 \mathrm{mmol} \mathrm{g}^{-1}$ wet wt day-

${ }^{1}$ for ocypodid crabs (Kristensen et al., 2008; Penha-Lopes et al., 2010). Average gastropod $\mathrm{CO}_{2}$ production in Penha-Lopes et al. (2010) $\left(0.011 \mathrm{mmol} \mathrm{g}^{-1} \mathrm{day}^{-1}\right)$ was similar to that in our study $\left(0.014 \mathrm{mmol} \mathrm{g}^{-1}\right.$ day $\left.^{-1}\right)$. width or length). They can be used for different purposes. Particularly, when estimating crab $\mathrm{CO}_{2}$ production related to crab burrow size (i.e. the diameter of burrow openings) (e.g. Cameron et al. (2019)), the relationship between $\mathrm{CO}_{2}$ production and carapace length rather than carapace width should be used as crabs walk side-ways. However, carapace length is not as good a measurement of animal body size as carapace width when different crab families are involved.

313 For example, our data suggest that ocypodid crabs had significantly smaller carapace length/width ratios $(0.59 \pm 0.002)$ than those of sesarmid crabs $(0.79 \pm 0.025)$.

The significant impact of feeding regimes on $\mathrm{CO}_{2}$ production of sesarmid crabs may be a result of the differences in carbon content of the diet and endogenic fuel. $\mathrm{CO}_{2}$ is a waste product

317 of oxidising reduced carbon compounds during crab metabolism. When sesarmid crabs were just

318 collected from the field, their main carbon source is mangrove leaves, which were found to have 319 a higher carbon content than the MPB (45.6\% vs. 30.6\%) (Bui \& Lee, 2014). This could account for the significant differences in $\mathrm{CO}_{2}$ production of crabs on collection and while feeding on the MPB. As small animals, when fasted for one day, our collected crabs may consume a mixture of recent diet (mangrove leaves) and stored carbohydrates, which are easier to decompose than the structural carbon-rich mangrove leaves and other organic compounds, e.g. lipids and proteins.

324 However, when they were fasted for two or three days, their energy source may shift to lipids and proteins, which are more difficult to be metabolised to $\mathrm{CO}_{2}$ than carbohydrates. This could 
account for the significantly higher $\mathrm{CO}_{2}$ production of crabs when they were fasted for one day but not more days than they fed on MPB. $\mathrm{CO}_{2}$ production of Carollia perspicilata was also reported to generally decline over time after feeding (Welch Jr et al., 2016), corroborating with our findings.

\section{Conclusions and Implications}

Our study tested the hypothesis that intertidal benthos breathe what they eat. This hypothesis is supported by the significantly higher $\delta^{13} \mathrm{C}$ of deposit feeders-respired $\mathrm{CO}_{2}$ than that of detritovore-respired $\mathrm{CO}_{2}$, and the significant difference in $\mathrm{CO}_{2}$ production under different feeding regimes due to different carbon content in diet or decomposability of carbon compounds in fuel.

Our study supports the notion that $\delta^{13} \mathrm{C}$ of benthos-respired $\mathrm{CO}_{2}$ can be used to differentiate food categories of the benthos, as has been demonstrated in mammals and other animals. It may be further applied to reveal the contribution of different food sources to their diet over short and long periods when combined with (compound-specific) stable isotope analyses of animal tissues and diets. For partitioning the food sources of intertidal animals, past studies combining stable isotope analyses of animal tissues and their diet have obvious limitations because they can only figure out their integrated food over long periods. However, intertidal benthos (e.g. crabs) may consume endogenous fuels such as lipids which are lower in ${ }^{13} \mathrm{C}$ (Stott et al., 1997) when they are inactive without feeding. There are also differences among endogenous fuels. For example, the difference in $\delta^{13} \mathrm{C}$ of synthesised lipids and carbohydrates are assumed to be -3\% (Carleton et al., 2004). Nevertheless, few studies can exclude the influence of endogenous fuels on the apparent food sources of intertidal benthos when using stable isotope analyses of animal tissues. 
349 Our study also reiterates the necessity of integrating the influence of benthos feeding regime

350 and size into estimating the contribution of intertidal benthos to $\mathrm{CO}_{2}$ emission rates from the

351 sediment surface. To date, a few studies have established benthos $\mathrm{CO}_{2}$ production related to crab

352 mass but are limited to a few families, e.g. ocypodid crabs (Penha-Lopes et al., 2010) and

353 sesarmid crabs in this study. The former study established a significant polynomial relationship

354 between crab $\mathrm{CO}_{2}$ production and body mass for ocypodid crabs, while we found a significant

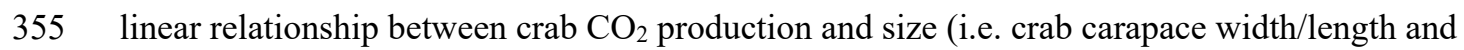

356 gastropod shell length) for sesarmid crabs. It highlights that the relationships between benthos

$357 \mathrm{CO}_{2}$ production and size indicators (i.e. weight or size) may be different depending on the

358 benthos taxa or families. Therefore, caution should be exercised in estimating benthos $\mathrm{CO}_{2}$

359 production from size indicators based on relationships developed for other benthos taxa.

360 Moreover, our study demonstrates the importance of considering the activity status of the

361 animals when estimating benthos $\mathrm{CO}_{2}$ production; in particular, a significant consideration for

362 up-scaling estimates on the contribution of benthos $\mathrm{CO}_{2}$ production to system sediment $\mathrm{CO}_{2}$

363 emission rates. The same benthic animals may forage alternatively on MPB and mangrove

364 litter/detritus, as well as switch between active-feeding and fasting over long periods.

366 Code availability

367 Computer codes are available upon request sent to Xiaoguang Ouyang.

368

369 Authors' contributions 
370

XO and SYL designed the study. XO conducted field survey, laboratory experiment and data analysis, and wrote the manuscript revised by SYL. CYL contributed to data acquisition and analysis.

\section{Competing interests}

The authors declare that they have no conflict of interest.

\section{Acknowledgements}

We thank Yan Ping Loo and Fen Guo for their assistance in collecting the crabs. Ms Kit Sum Leung (The University of Hong Kong) is thanked for conducting the stable isotope analysis.

Professor Brian Fry (Griffith University, Australia) is acknowledged for his constructive advice on the initial manuscript drafts. Xiaoguang Ouyang was supported by a Postdoctoral Fellowship at The Chinese University of Hong Kong.

\section{References}

Bui, T. H. H., \& Lee, S. Y. (2014). Does 'You Are What You Eat' Apply to Mangrove Grapsid Crabs? PLoS One, 9(2), e89074. doi:10.1371/journal.pone.0089074

Caloin, M. (2004). Modeling of lipid and protein depletion during total starvation. American Journal of Physiology Endocrinology Metabolism, 287(4), E790-E798.

Cameron, C., Hutley, L. B., Friess, D. A., \& Munksgaard, N. C. (2019). Hydroperiod, soil moisture and bioturbation are critical drivers of greenhouse gas fluxes and vary as a function of landuse change in mangroves of Sulawesi, Indonesia. Science of the Total Environment, 654, 365-377. doi:doi.org/10.1016/j.scitotenv.2018.11.092 
https://doi.org/10.5194/bg-2020-424

Preprint. Discussion started: 24 November 2020

(c) Author(s) 2020. CC BY 4.0 License.

393

394

395

396

397

398

399

400

401

402

403

404

405

406

407

408

409

410

411

412

413

Carleton, S. A., Wolf, B. O., \& Del Rio, C. M. (2004). Keeling plots for hummingbirds: a method to estimate carbon isotope ratios of respired $\mathrm{CO}_{2}$ in small vertebrates. Oecologia, 141(1), 1-6.

Caro, T. (1994). Cheetahs of the Serengeti Plains: group living in an asocial species. USA: University of Chicago Press.

Castellini, M. A., \& Rea, L. D. (1992). The biochemistry of natural fasting at its limits. Experientia, 48(6), 575-582. doi:10.1007/bf01920242

Chong, V., Low, C., \& Ichikawa, T. (2001). Contribution of mangrove detritus to juvenile prawn nutrition: a dual stable isotope study in a Malaysian mangrove forest. Marine Biology, 138(1), 77-86.

Dawson, T. E., Mambelli, S., Plamboeck, A. H., Templer, P. H., \& Tu, K. P. (2002). Stable isotopes in plant ecology. Annual review of ecology systematics, 33(1), 507-559.

DeNiro, M. J., \& Epstein, S. (1977). Mechanism of carbon isotope fractionation associated with lipid synthesis. Science, 197(4300), 261-263.

Engel, S., Lease, H. M., McDowell, N. G., Corbett, A. H., \& Wolf, B. O. (2009). The use of tunable diode laser absorption spectroscopy for rapid measurements of the $\delta^{13} \mathrm{C}$ of animal breath for physiological and ecological studies. Rapid Communications in Mass Spectrometry, 23(9), 1281-1286. doi:10.1002/rcm.4004

Fox, J., \& Weisberg, S. (2011). An $\{\mathrm{R}\}$ Companion to Applied Regression, Second Edition. Thousand Oaks CA: Sage.

Fry, B. (2006). Stable Isotope Ecology. New York, USA: Springer. 
https://doi.org/10.5194/bg-2020-424

Preprint. Discussion started: 24 November 2020

(c) Author(s) 2020. CC BY 4.0 License.

(c) (i)

414 Jacotot, A., Marchand, C., \& Allenbach, M. (2018). Tidal variability of $\mathrm{CO}_{2}$ and $\mathrm{CH}_{4}$ emissions

415 from the water column within a Rhizophora mangrove forest (New Caledonia). Science

$416 \quad$ of the Total Environment, 631, 334.

417 Katz, L. C. (1980). Effects of burrowing by the fiddler crab, Uca pugnax (Smith). Estuarine and $418 \quad$ Coastal Marine Science, 11(2), 233-237.

419 Keeling, C. D. (1961). A mechanism for cyclic enrichment of carbon-12 by terrestrial plants.

$420 \quad$ Geochimica et Cosmochimica Acta, 24(3-4), 299-313.

421 Kristensen, E., Flindt, M. R., Ulomi, S., Borges, A. V., Abril, G., \& Bouillon, S. (2008).

422

423 Emission of $\mathrm{CO}_{2}$ and $\mathrm{CH}_{4}$ to the atmosphere by sediments and open waters in two Tanzanian mangrove forests. Marine Ecology Progress Series, 370, 53-67. doi:10.3354/meps07642

Kristensen, E., Lee, S. Y., Mangion, P., Quintana, C. O., \& Valdemarsen, T. (2017). Trophic discrimination of stable isotopes and potential food source partitioning by leaf-eating crabs in mangrove environments. Limnology and Oceanography, 62(5), 2097-2112.

Lee, S. Y. (2008). Mangrove macrobenthos: assemblages, services, and linkages. Journal of Sea Research, 59(1-2), 16-29. doi:10.1016/j.seares.2007.05.002

Lee, S. Y., Primavera, J. H., Dahdouh-Guebas, F., McKee, K., Bosire, J. O., Cannicci, S., Diele, K., Fromard, F., Koedam, N., Marchand, C., Mendelssohn, I., Mukherjee, N., \& Record, S. (2014). Ecological role and services of tropical mangrove ecosystems: a reassessment. Global Ecology and Biogeography, 23, 726-743. doi:10.1111/geb.12155

434 McCue, M. D., \& Welch, K. C. (2016). 13 C-Breath testing in animals: theory, applications, and 435 future directions. Journal of Comparative Physiology B, 186(3), 265-285. 
Munksgaard, N. C., Cheesman, A. W., Wurster, C. M., Cernusak, L. A., \& Bird, M. I. (2014).

Microwave extraction-isotope ratio infrared spectroscopy (ME-IRIS): a novel technique for rapid extraction and in-line analysis of $\delta^{18} \mathrm{O}$ and $\delta^{2} \mathrm{H}$ values of water in plants, soils and insects. Rapid Communications in Mass Spectrometry, 28(20), 2151-2161.

Ouyang, X., Lee, S. Y., \& Connolly, R. M. (2017). Structural equation modelling reveals factors regulating surface sediment organic carbon content and $\mathrm{CO}_{2}$ efflux in a subtropical mangrove. Sci. Total. Environ., 578, 513-522. doi:10.1016/j.scitotenv.2016.10.218

Ouyang, X., Lee, S. Y., \& Connolly, R. M. (2018). Using isotope labeling to partition sources of $\mathrm{CO}_{2}$ efflux in newly established mangrove seedlings. Limnology and Oceanography, 63, 731-740. doi:10.1002/lno.10663

Ouyang, X., Guo, F., \& Lee, S. Y. (2020). The impact of super-typhoon Mangkhut on sediment nutrient density and fluxes in a mangrove forest in Hong Kong. Science of the Total Environment, doi:10.1016/j.scitotenv.2020.142637

Passey, B. H., Robinson, T. F., Ayliffe, L. K., Cerling, T. E., Sponheimer, M., Dearing, M. D., Roeder, B. L., \& Ehleringer, J. R. (2005). Carbon isotope fractionation between diet, breath $\mathrm{CO} 2$, and bioapatite in different mammals. Journal of Archaeological Science, $32(10), 1459-1470$.

Penha-Lopes, G., Kristensen, E., Flindt, M., Mangion, P., Bouillon, S., \& Paula, J. (2010). The role of biogenic structures on the biogeochemical functioning of mangrove constructed wetlands sediments-a mesocosm approach. Marine Pollution Bulletin, 60(4), 560-572.

R Core Team. (2014). A Language and Environment for Statistical Computing, R Foundation for Statistical Computing, Vienna, Austria. 
https://doi.org/10.5194/bg-2020-424

Preprint. Discussion started: 24 November 2020

(c) Author(s) 2020. CC BY 4.0 License.

Rolston, D. (1986). Gas flux. In A. Klute (Ed.), Methods of Soil Analysis: Part 1-Physical Mineralogical Methods (pp. 1103-1119). Madison, USA: American Society of Agronomy-Soil Science Society of America.

Rosentreter, J. A., Maher, D., Erler, D., Murray, R., \& Eyre, B. (2018). Seasonal and temporal $\mathrm{CO}_{2}$ dynamics in three tropical mangrove creeks-A revision of global mangrove $\mathrm{CO} 2$ emissions. Geochimica et Cosmochimica Acta, 222, 729-745.

Russell-Hunter, W. D. (1970). Aquatic productivity: Introduction to some basic aspects of biological oceanography and limnology: Collier-Macmillan, London, UK.

Sea, M. A., Garcias-Bonet, N., Saderne, V., \& Duarte, C. M. (2018). Carbon dioxide and methane fluxes at the air-sea interface of Red Sea mangroves. Biogeosciences, 15, 53655375. doi:10.5194/bg-2018-37.

Stott, A. W., Davies, E., Evershed, R. P., \& Tuross, N. (1997). Monitoring the routing of dietary and biosynthesised lipids through compound-specific stable isotope $\left(\delta^{13} \mathrm{C}\right)$ measurements at natural abundance. Naturwissenschaften, 84(2), 82-86.

Vernberg, F. J. (1993). Salt-marsh processes: a review. Environmental Toxicology and Chemistry, 12(12), 2167-2195.

Voigt, C. C., Grasse, P., Rex, K., Hetz, S. K., \& Speakman, J. R. (2008). Bat breath reveals metabolic substrate use in free-ranging vampires. Journal of Comparative Physiology B, 178(1), 9-16.

Wachter, B., Blanc, A.-S., Melzheimer, J., Höner, O. P., Jago, M., \& Hofer, H. (2012). An advanced method to assess the diet of free-ranging large carnivores based on scats. PLoS One, 7(6), e38066. 
https://doi.org/10.5194/bg-2020-424

Preprint. Discussion started: 24 November 2020

(C) Author(s) 2020. CC BY 4.0 License.

(c) (i)

480 Welch Jr, K. C., Péronnet, F., Hatch, K. A., Voigt, C. C., \& McCue, M. D. (2016). Carbon

481 stable-isotope tracking in breath for comparative studies of fuel use. Ann. N. Y. Acad. Sci,

482 $1365,15-32$

483 


\section{$484 \quad$ Figure legends}

485 Fig.1 A conceptual model showing the process of measuring $\mathrm{CO}_{2}$ production and $\delta^{13} \mathrm{C}$ of

486 respired $\mathrm{CO}_{2}$ by CRDS: the closed container, a sesarmid crab, the syringe used to collect gas

487 from the container, a stop-cock, and CRDS. CRDS denotes cavity ring-down spectroscopy.

489 Fig. 2 The variation of $\delta^{13} \mathrm{C}$ of benthos-respired $\mathrm{CO}_{2}$ with different benthos taxa (a), dominant

490 feeding habits (b) and diets (c), as well as $\mathrm{C} / \mathrm{N}$ of diets (d). Bars with different letters have

491 significantly different values.

492

493 Fig. 3 The variation of $\delta^{13} \mathrm{C}$ of crab-respired $\mathrm{CO}_{2}$ with different feeding regimes. Bars with 494 different letters are significantly different.

495

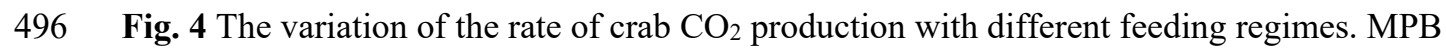

497 denotes microphytobenthos. Bars with different letters have significantly different $\mathrm{CO}_{2}$

498 production.

499

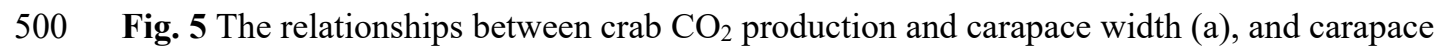

501 length (b), as well as between gastropod $\mathrm{CO}_{2}$ production and shell length (c). 
https://doi.org/10.5194/bg-2020-424

Preprint. Discussion started: 24 November 2020

(c) Author(s) 2020. CC BY 4.0 License.

Fig. 1

503

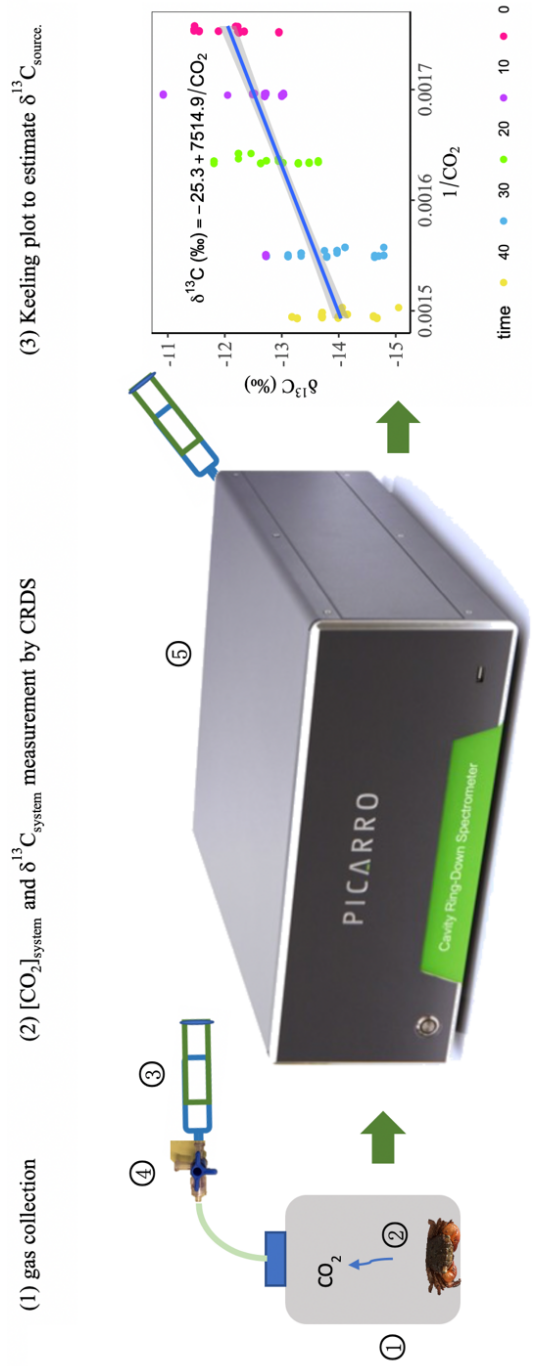


504

505

a)

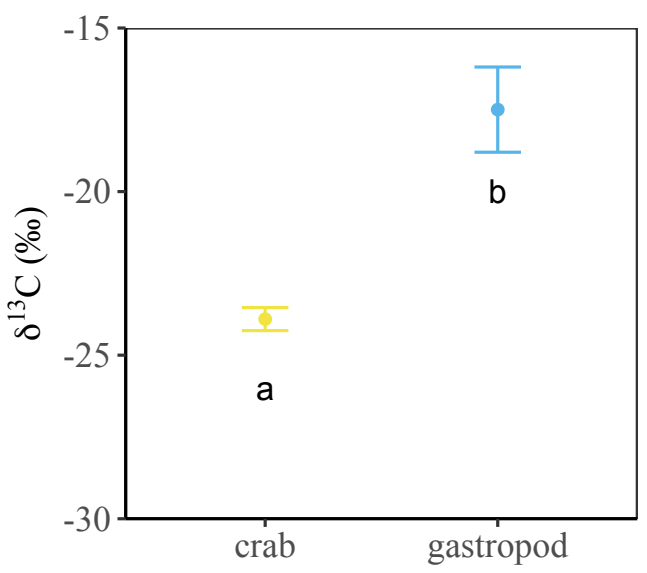

507

c)

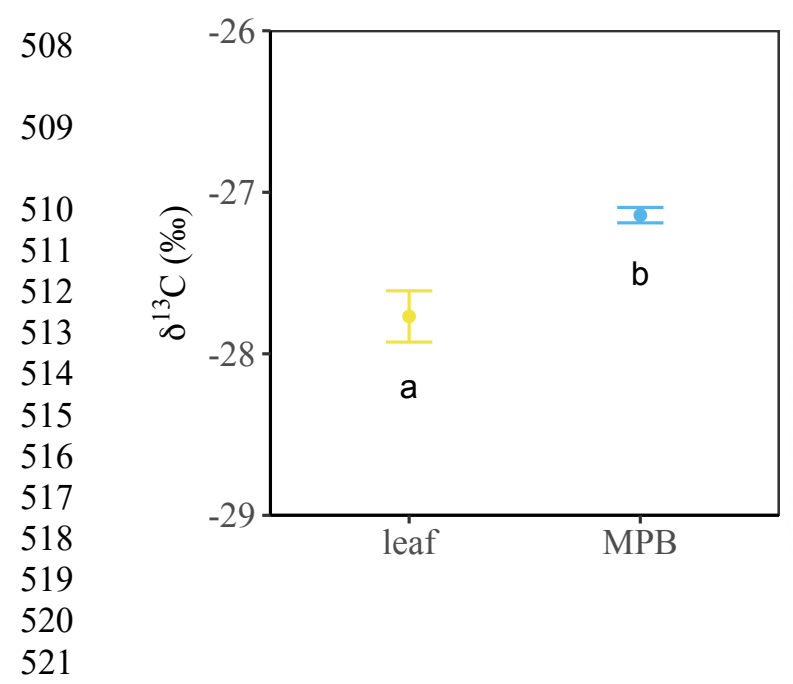

b)

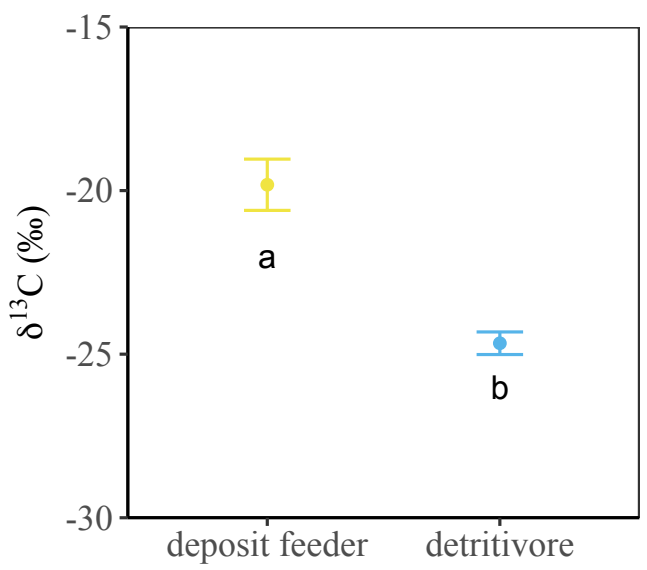

d)

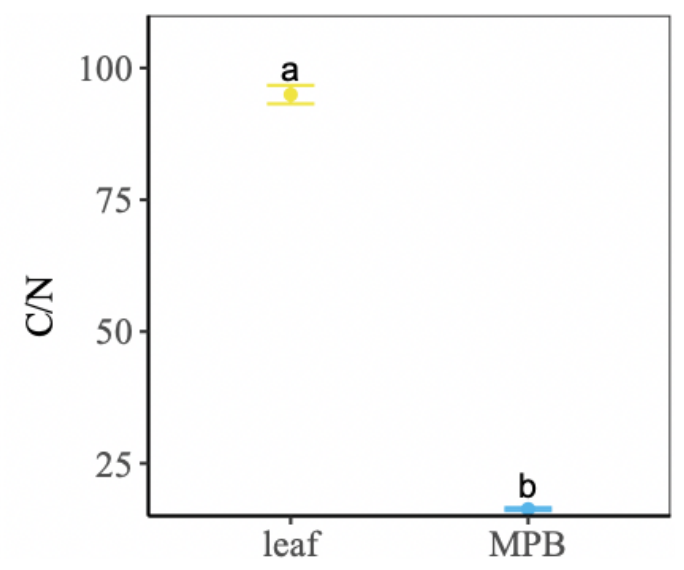


https://doi.org/10.5194/bg-2020-424

Preprint. Discussion started: 24 November 2020

(c) Author(s) 2020. CC BY 4.0 License.

(c) (i)

$522 \quad$ Fig. 3

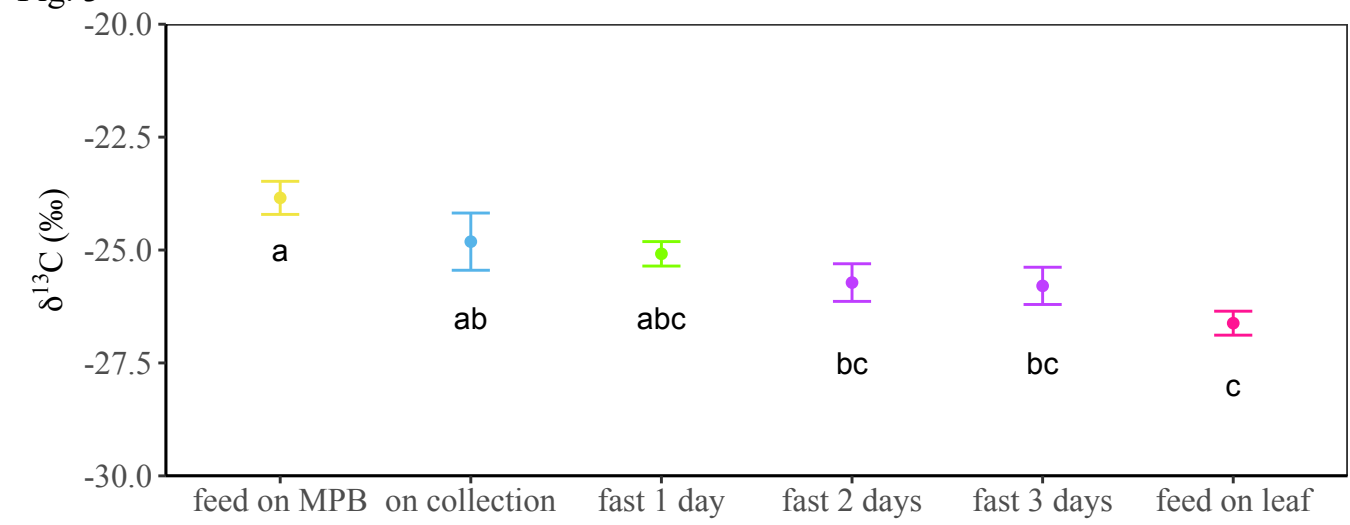


https://doi.org/10.5194/bg-2020-424

Preprint. Discussion started: 24 November 2020

(c) Author(s) 2020. CC BY 4.0 License.

Fig. 4

525

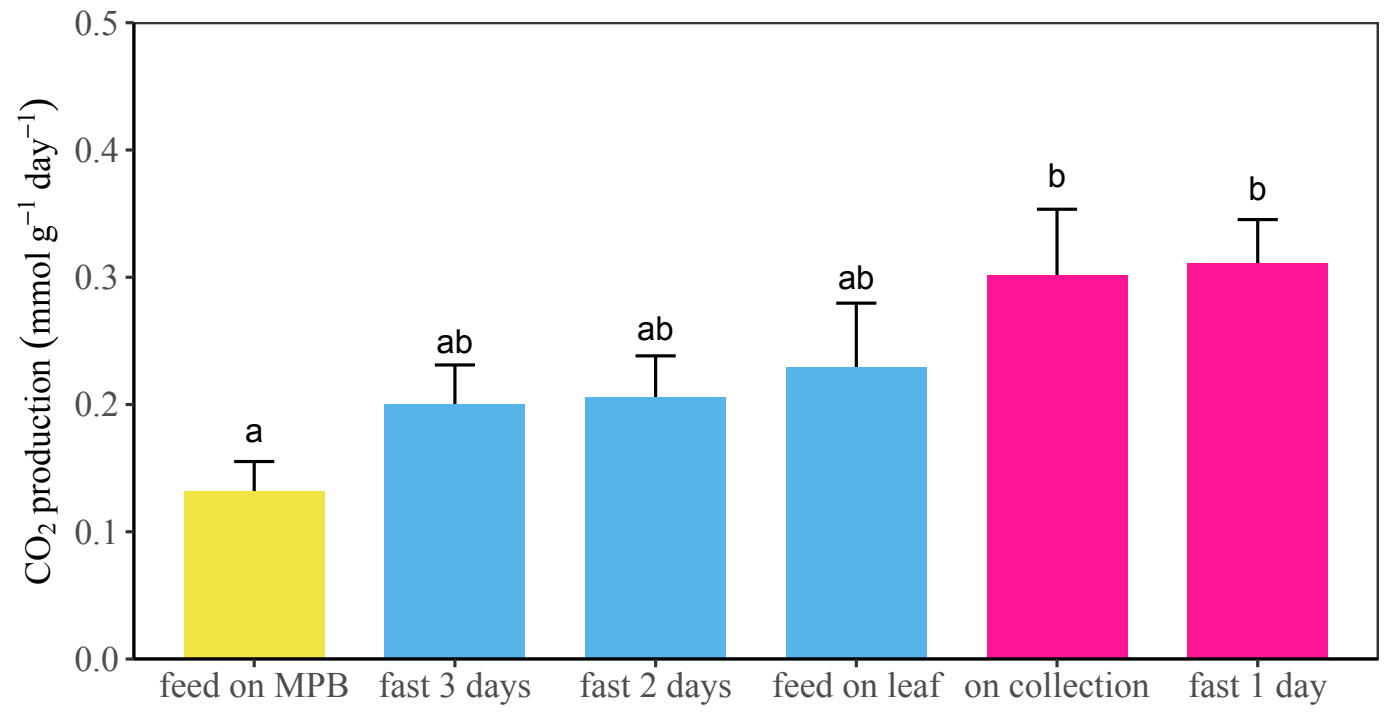


https://doi.org/10.5194/bg-2020-424

Preprint. Discussion started: 24 November 2020

(c) Author(s) 2020. CC BY 4.0 License.

Fig. 5

545 a)

546

a)

547

548

549

550

551

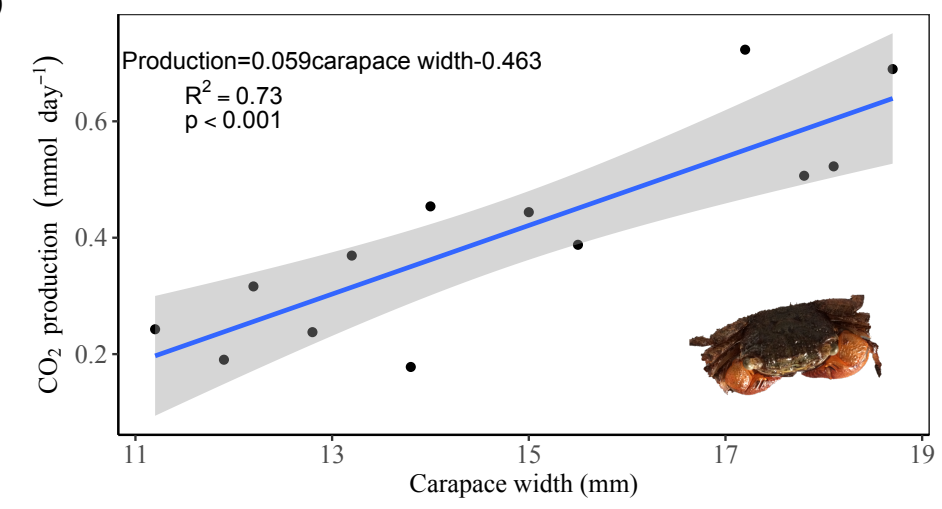

552 b)

553

554

555

556

557

558

c)

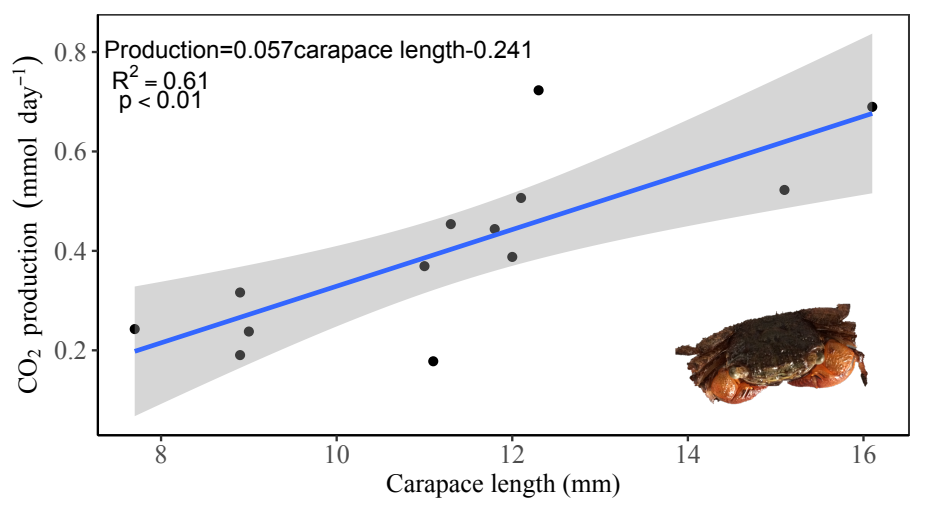

559

560

561

562

563

564

565

566

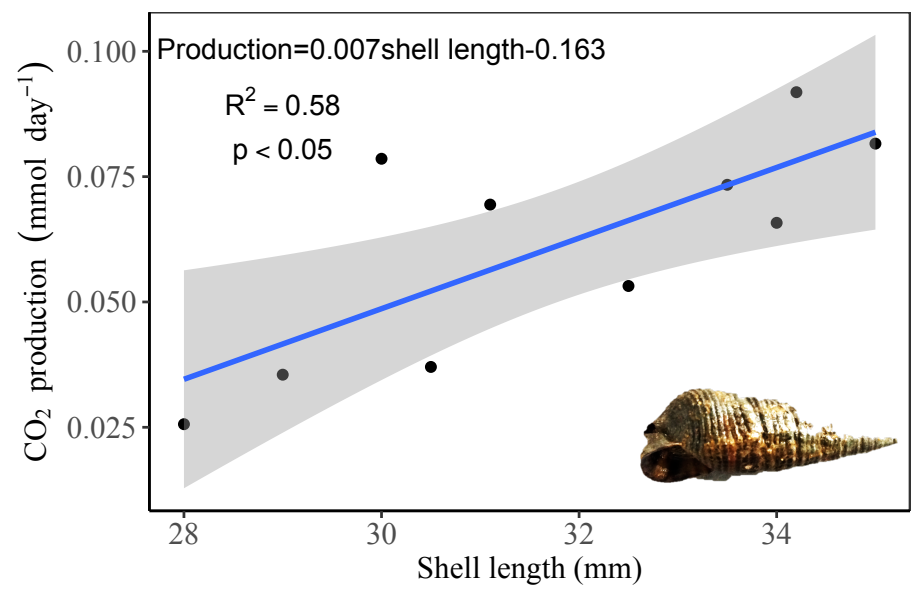


568 Table 1 Isotopic fractionation between mangrove animal respired $\mathrm{CO}_{2}$ and their diets. MPB 569 denotes microphytobenthos.

570

\begin{tabular}{|c|c|c|c|c|c|}
\hline \multicolumn{2}{|l|}{ Benthos taxa } & \multicolumn{2}{|l|}{ Diet } & \multicolumn{2}{|c|}{ Isotopic fractionation } \\
\hline $\begin{array}{l}\delta^{13} \mathrm{C} \text { of crab } \\
\text { respired } \mathrm{CO}_{2}\end{array}$ & $\begin{array}{l}\delta^{13} \mathrm{C} \text { of } \\
\text { gastropod } \\
\text { respired } \mathrm{CO}_{2}\end{array}$ & $\begin{array}{l}\delta^{13} \mathrm{C} \text { of } \\
\mathrm{MPB}\end{array}$ & $\begin{array}{l}\delta^{13} \mathrm{C} \text { of } \\
\text { yellow } \\
\text { leaves }\end{array}$ & $\Delta^{13} \mathrm{C}_{\text {benthos-MPB }}$ & $\Delta^{13} \mathrm{C}_{\text {benthos-leaves }}$ \\
\hline$-23.9 \pm 0.4 \%$ & $-17.5 \pm 1.3 \%$ & $-27.1 \pm 0.05 \%$ & $-27.8 \pm 0.2 \% 0$ & $\begin{array}{l}3.2 \% \mathrm{o}^{\mathrm{a}} \\
9.6 \% \mathrm{o}^{\mathrm{b}}\end{array}$ & $3.9 \% 0^{\mathrm{a}}$ \\
\hline Feeding habit & & Diet & & Isotopic fractio & ation \\
\hline $\begin{array}{l}\delta^{13} \mathrm{C} \text { of } \\
\text { deposit-feeder } \\
\text { respired } \mathrm{CO}_{2}\end{array}$ & $\begin{array}{l}\delta^{13} \mathrm{C} \text { of } \\
\text { detritivore } \\
\text { respired } \mathrm{CO}_{2}\end{array}$ & $\begin{array}{l}\delta^{13} \mathrm{C} \text { of } \\
\mathrm{MPB}\end{array}$ & $\begin{array}{l}\delta^{13} \mathrm{C} \text { of } \\
\text { yellow } \\
\text { leaves }\end{array}$ & $\begin{array}{l}\Delta^{13} \mathrm{C}_{\text {deposit- }} \\
\text { feeder-MPB }\end{array}$ & $\begin{array}{l}\Delta^{13} \mathrm{C}_{\text {detritivore- }} \\
\text { leaves }\end{array}$ \\
\hline$-19.8 \pm 0.8 \%$ о & $-24.7 \pm 0.3 \%$ & $-27.1 \pm 0.05 \%$ & $-27.8 \pm 0.2 \% 0$ & $7.3 \%$ & $3.1 \%$ \\
\hline
\end{tabular}

${ }^{\mathrm{a}} \mathrm{crab},{ }^{\mathrm{b}}$ gastropod 